Наносистели, нанолатеріали, нанотехнології Nanosistemi, Nanomateriali, Nanotehnologii 2019 , т. 17 , № 2, сc. 343-352
() 2019 ІМФ (Інститут металофізики ім. Г. В. Курдюмова НАН України) Надруковано в Україні. Фотокопіювання дозволено тільки відповідно до ліцензії

PACS numbers: 61.46.Hk, 61.72.J-, 61.72.S-, 68.37.Hk, 78.30.Hv, 81.07.Bc, 82.75.-z

\title{
Studying Solid Solutions of Substitution of Pb with Sm in Lead-Sodium Apatite Structure
}

\author{
Mohammed A. B. Abdul Jabar \\ College of Science, Al-Karkh University of Science, \\ Al-Karkh Side, Haifa St. Hamada Palace, \\ 10001 Baghdad, Iraq
}

The substitution of lead with samarium in the $\mathrm{Pb}_{(8-x)} \mathrm{Na}_{2} \mathrm{Sm}_{x}\left(\mathrm{PO}_{4}\right)_{6} \mathrm{O}_{x / 2}$ solid solutions corresponding to the scheme $2 \mathrm{~Pb}^{2+}+\square \rightarrow 2 \mathrm{Sm}^{3+}+\mathrm{O}^{2-}$ is examined by X-ray diffractometer, IR-spectroscopy and scanning electron microscopy. The compositions with $x=0,0.20,0.40,0.60,0.80,1.0,1.2,1.4$, 1.6, 1.8, and 2.0 are studied. All samples are synthesized by ceramic methods. The cycle of operations is carried out until a constant phase composition is accomplished. The total calcination time at a temperature of $850^{\circ} \mathrm{C}$ is 60 hours. Rietveld method displays that samarium ion $\left(\mathrm{Sm}^{3+}\right)$ is located in positions of the $\mathrm{Pb}(2)$ type, and the distance in a polyhedron of $\mathrm{Pb}(2)$, which has the structure of apatite, is decreased.

Заміщення $\mathrm{Pb}$ на $\mathrm{Sm}$ у твердих розчинах $\mathrm{Pb}_{(8-x)} \mathrm{Na}_{2} \mathrm{Sm}_{x}\left(\mathrm{PO}_{4}\right)_{6} \mathrm{O}_{x / 2}$, відповідно схемі $2 \mathrm{~Pb}^{2+}+\square \rightarrow 2 \mathrm{Sm}^{3+}+\mathrm{O}^{2^{-}}$, досліджується за допомогою рентґенівського дифрактометра, ІЧ-спектроскопії та сканувальної електронної мікроскопії. Вивчено композиції з $x=0,0,20,0,40,0,60,0,80,1,0$, $1,2,1,4,1,6,1,8,2,0$. Всі зразки було синтезовано керамічними методами. Цикл операцій виконується до тих пір, поки не буде досягнутий постійний фазовий склад. Загальний час прожарювання за температури у $850^{\circ} \mathrm{C}$ становить 60 годин. Рітвельдова метода показує, що йон Самарію $\left(\mathrm{Sm}^{3+}\right)$ знаходиться в положеннях типу $\mathrm{Pb}(2)$, а віддаль у багатограннику $\mathrm{Pb}(2)$, що має структуру апатиту, зменшується.

Замещение свинца самарием в твёрдых растворах $\mathrm{Pb}_{(8-x)} \mathrm{Na}_{2} \mathrm{Sm}_{x}\left(\mathrm{PO}_{4}\right)_{6} \mathrm{O}_{x / 2}$, соответствующее схеме $2 \mathrm{~Pb}^{2+}+\square \rightarrow 2 \mathrm{Sm}^{3+}+\mathrm{O}^{2-}$, исследуется с помощью рентгеновского дифрактометра, ИК-спектроскопии и сканирующей электронной микроскопии. Изучены композиции с $x=0,0,20,0,40$, $0,60,0,80,1,0,1,2,1,4,1,6,1,8,2,0$. Все образцы синтезированы керамическими методами. Цикл операций выполняется до тех пор, пока не будет достигнут постоянный фазовый состав. Общее время прокаливания при температуре $850^{\circ} \mathrm{C}$ составляет 60 часов. Метод Ритвельда показывает, что ион самария $\left(\mathrm{Sm}^{3+}\right)$ находится в положениях типа 
$\mathrm{Pb}(2)$, а расстояние в многограннике $\mathrm{Pb}(2)$, имеющем структуру апатита, уменьшается.

Key words: lead, apatite, samarium, substitutional solid solution.

Ключові слова: Свинець, апатит, Самарій, твердий розчин заміщення.

Ключевые слова: свинец, апатит, самарий, твердый раствор замещения.

(Received 13 December 2018)

\section{INTRODUCTION}

Compounds with apatite structure have the composition $M_{10}\left(E \mathrm{O}_{4}\right)_{6}(Z)_{2}$, where $M$ is a cation with single, double, and trivalent charges $\left(\mathrm{Na}^{+}, \mathrm{K}^{+}\right.$, $\mathrm{Ca}^{2+}, \mathrm{Sr}^{2+}, \mathrm{Ba}^{2+}, \mathrm{Pb}^{2+}, \mathrm{Cd}^{2+}, \mathrm{Eu}^{3+}, \mathrm{La}^{3+}$, lanthanide ions, and so on), $E$ is a cation with four, five, and hexavalent charges, which look like $\mathrm{Si}^{4^{+}}, \mathrm{P}^{5+}$, $\mathrm{V}^{5+}, \mathrm{As}^{5+}, \mathrm{S}^{6+}, \mathrm{Cr}^{6+}$, etc. $), Z$ is an anion of $\mathrm{OH}^{-}, \mathrm{F}^{-}, \mathrm{Cl}^{-}, \mathrm{Br}^{-}, \mathrm{I}^{-}, \mathrm{O}^{2-}$ or vacancies. Apatite structure is described by the occurrence of two structurally non-equivalent positions in the cation sublattice predictably designated as $M(1)$ and $M(2)$. Position (1) has an environment of nine oxygen atoms (each of which is a part of the tetrahedra $\mathrm{PO}_{4}$ ), forming a coordination polyhedron nine-vertex. The coordination environment of the $M(2)$ position is the six oxygen atoms of the $\mathrm{PO}_{4}$ tetrahedra and $\mathrm{F}^{-}$ $\left(\mathrm{Cl}^{-}, \mathrm{OH}^{-}, \mathrm{O}^{2-}\right.$, and so on) ions that form the coordination polyhedron seven-vertex. Equilateral triangles $M(2)$ in the structure of apatite form a channel, in which $\mathrm{F}^{-}\left(\mathrm{Cl}^{-}, \mathrm{OH}^{-}, \mathrm{O}^{2-}\right.$, and others) ions are located [1].

Lately, the attention of researchers in the compounds with such a structure has not weakened, at least, for two reasons. First, they have a complex of practically important properties and can be used, for example, as solid stable forms for the application of radioactive waste, sorbents [2,3], solid electrolytes [4], catalysts [5], luminescent substances, laser materials [6], and in many other cases. Secondly, they have a wide range of isomorphous substitutions, which allow them to regulate their properties by introducing isomorphic components. In particular, luminescent and laser materials are obtained by partially replacing ions of divalent elements in the structure of apatite with rare-earth ions and other elements [7-8].

Therefore, the study of heterovalent substitutions according to the $M^{2+}+Z^{-} \rightarrow L n^{3+}+\mathrm{O}^{2-}$ scheme in $M_{(10-x)} L n_{x}\left(E \mathrm{O}_{4}\right)_{6} Z_{(2-x)} \mathrm{O}_{x}$ systems, where $M^{2+}$ ions of divalent elements and $L^{3+}$ ions of rare-earth elements, is topical. Thus, substitutions of alkaline earths for most rare-earth elements have been studied [9-11]. However, in spite of the fact that the ionic radius of lead is close in size to the radii of the ions of alkaline earth elements, there is no information in the 
literature on the substitution of lead for rare-earth elements in the systems $\mathrm{Pb}_{(10-x)} \operatorname{Ln}_{x}\left(\mathrm{PO}_{4}\right)_{6} \mathrm{OH}_{(2-x)} \mathrm{O}_{x}$. Advantage of systems with lead apatites is a significantly lower synthesis temperature $\left(850^{\circ} \mathrm{C}\right)$ [12] in comparison with apatite of alkaline-earth elements (1200$1450^{\circ} \mathrm{C}$ ) [9], which simplifies the synthesis procedure and promotes the production of finely dispersed grains.

Thus, it is of interest to examine substitutions according to the scheme $2 \mathrm{~Pb}^{2+}+\square \rightarrow 2 \mathrm{Sm}^{3+}+\mathrm{O}^{2-}$ described for the systems $\mathrm{Pb}_{(8-x)} \mathrm{Na}_{2} \mathrm{Sm}_{x}\left(\mathrm{PO}_{4}\right)_{6} \mathrm{O}_{x / 2}$ (Ln = Ce, Pr, Nd, Sm, Eu, Gd, Tb, Dy, Ho, Er). However, these systems were studied only for compounds with $x=0.25$ [13]. In this paper, the substitution by samarium for lead in the structure $\mathrm{Pb}_{8} \mathrm{Na}_{2}\left(\mathrm{PO}_{4}\right)_{6}$ in a wide range of compositions is studied.

\section{EXPERIMENTAL}

To synthesize the samples of the $\mathrm{Pb}_{(8-x)} \mathrm{Sm}_{x} \mathrm{Na}_{2}\left(\mathrm{PO}_{4}\right)_{6} \mathrm{O}_{x / 2}(0 \leq x \leq 2)$ system, $\mathrm{PbO}$ (chemically pure), $\mathrm{Sm}_{2} \mathrm{O}_{3}\left(99.99 \%\right.$ ), $\mathrm{Na}_{2} \mathrm{CO}_{3}$ (chemically pure) and $\left(\mathrm{NH}_{4}\right)_{2} \mathrm{HPO}_{4}$ (analytical grade) were used as initial reagents, which are provided by Sinbias (Ukraine). The compositions with $x=0,0.20$, $0.40,0.60,0.80,1.0,1.2,1.4,1.6,1.8$, and 2.0 were studied.

All samples were synthesized by ceramic methods. The starting materials weighed in stoichiometric proportions were mixed in an agate mortar for 20 minutes and calcinated in alumina crucibles at a temperature of $300^{\circ} \mathrm{C}$ for 3 hours, after that the temperature was elevated to $850^{\circ} \mathrm{C}$, at which calcination was carried out for 5 hours. After calcination, the samples were homogenized and investigated by X-ray phase analysis (XRD) to determine the phase composition. After that, the samples were again calcinated at a temperature of $850^{\circ} \mathrm{C}$. This cycle of operations was carried out until a constant phase composition was accomplished. As a result, the total calcination time at a temperature of $850^{\circ} \mathrm{C}$ was 60 hours.

$\mathrm{X}$-ray phase analysis was performed on a modernized diffractometer DRON-3 $\left(\mathrm{Cu} K_{\alpha}\right.$ radiation, Ni-filter) with electron-controlled and results-based processing. The speed of the counter during determining the phase composition of the samples was $2^{\circ} / \mathrm{min}$. To refine the crystal structure by the Rietveld method, we used an array of data obtained from a powder X-ray diffraction pattern taken in the angular interval from 15 to $140^{\circ}(2 \theta)$. The scanning step and the exposure time at each point were 0.05 and 3 seconds, respectively. The refinement was carried out using the program FULLPROF.2k (version 3.40) [14] with the graphical interface WinPLOTR [15].

IR spectra were measured by potassium bromide $(\mathrm{KBr})$ method using a Fourier transform infrared spectrometer FT-IR TENSOR 27 (Bruker Optics) in the wave-number range 4000-400 $\mathrm{cm}^{-1}$. Samples calcinated to $600^{\circ} \mathrm{C}$ to remove adsorbed water and then compressed 
on a pellet were prepared by crushing $1 \mathrm{mg}$ samples with $600 \mathrm{mg}$ $\mathrm{KBr}$ under a pressure of $900 \mathrm{MPa}$.

Grain-sizes and semi-quantitative elemental analyses were performed on a scanning electron microscope JSM-6490LV (JEOL, Japan)

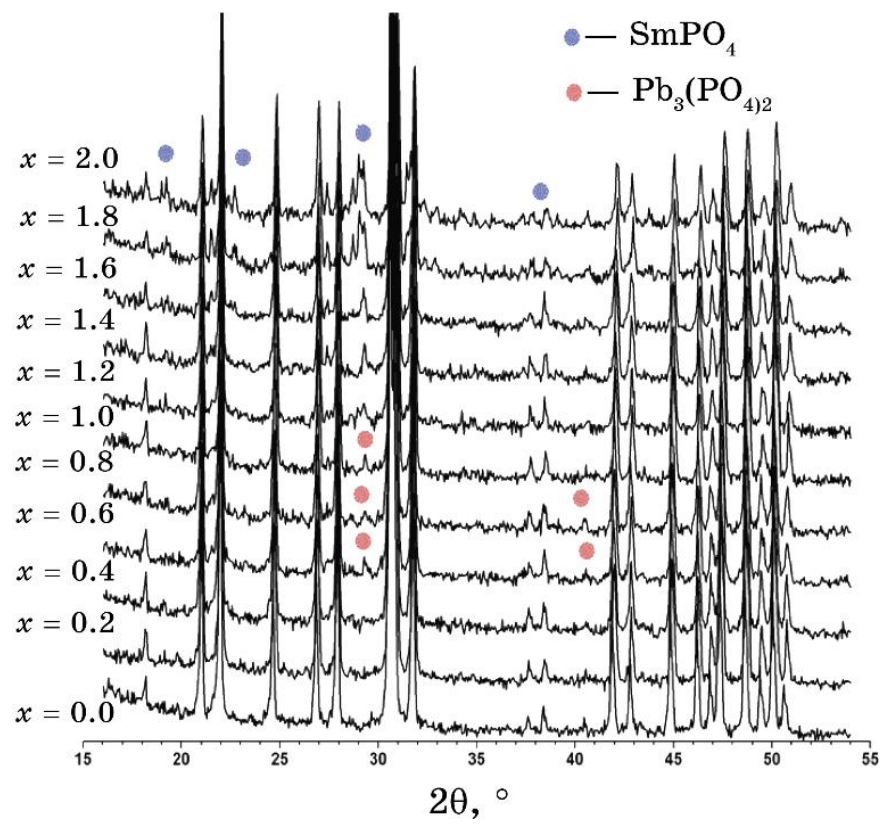

Fig. 1. The X-ray diffraction patterns of $\mathrm{Pb}_{(8-x)} \mathrm{Sm}_{x} \mathrm{Na}_{2}\left(\mathrm{PO}_{4}\right)_{6} \mathrm{O}_{x / 2}$.

TABLE 1. Phase composition of samples of the $\mathrm{Pb}_{(8-x)} \mathrm{Na}_{2} \mathrm{Sm}_{x}\left(\mathrm{PO}_{4}\right)_{6} \mathrm{O}_{x / 2}$ system.

\begin{tabular}{c|c|c|c}
\hline \multirow{2}{*}{$x$} & \multicolumn{3}{|c}{ The relative intensity $\left(I / I_{\text {max }}\right) \times 100[\%]$} \\
& \multicolumn{2}{|c}{ of the maximum phase lines with the structure } \\
\cline { 2 - 4 } & $\mathrm{Pb}_{8} \mathrm{Na}_{2}\left(\mathrm{PO}_{4}\right)_{6}$ & $\mathrm{SmPO}_{4}$ & $\mathrm{~Pb}_{3}\left(\mathrm{PO}_{4}\right)_{2}$ \\
\hline 0.00 & 100 & - & - \\
0.20 & 100 & - & - \\
0.40 & 100 & - & - \\
0.60 & 100 & - & 5 \\
0.80 & 100 & - & 4 \\
1.00 & 100 & - & 5 \\
1.20 & 100 & 8 & - \\
1.40 & 100 & 11 & - \\
1.60 & 100 & 14 & - \\
1.80 & 100 & 18 & - \\
2.00 & 100 & 20 & - \\
\hline
\end{tabular}


using an X-ray energy dispersive spectrometer INCA Penta FETx3 (OXFORD Instruments, England).

The difference in the experimental and theoretical contents of the elements did not exceed $2 \%$ that is acceptable for this method of an analysis in such systems [16].

\section{RESULTS AND DISCUSSION}

X-ray diffraction samples of this system show that the constancy of the phase composition of the solid solutions was obtained after 60 hours of calcination. The results of phase analysis of samples of this system are presented in Table 1 and Fig. 1.

As can be seen from the data above, the apatite phase is formed in the entire investigated region of the compositions, and the relative intensity of the peaks of this phase is of $100 \%$. In the composition range up to $x=0-0.4$, only the peaks of the phase with apatite structure are present in the X-ray patterns, and no peaks of other phases are present. In X-ray diffraction patterns of the composition $x=0.6-1.0$, in addition to the peaks of the apatite structure, additional peaks, which are not related to the $\mathrm{Pb}_{8} \mathrm{Na}_{2}\left(\mathrm{PO}_{4}\right)_{6}$ phase, are also present. These peaks belong to the phase of lead phosphate $\mathrm{Pb}_{3}\left(\mathrm{PO}_{4}\right)_{2}$, but they were not identified with sufficient reliability [17]. In the X-ray pattern of samples of composition $x=1.2-2.0$, in addition to the apatite peaks, there are also peaks of samarium phosphate $\mathrm{SmPO}_{4}$, where the intensity increases with increasing $x$ in the range of $8-20 \%$.

Substitution by samarium for lead in the $\mathrm{Pb}_{(8-x)} \mathrm{Na}_{2} \mathrm{Sm}_{x}\left(\mathrm{PO}_{4}\right)_{6} \mathrm{O}_{x / 2}$ system is accompanied by a change in the parameters of the unit cell that is shown below (Fig. 2). From Figure 2, with increasing $x(x=0.0-1.2)$, parameters $a$ and $c$ are decreasing that is because the ionic radius of $\mathrm{Sm}^{3+}$ $(1.098 \AA)$ is smaller than the ionic radius of $\mathrm{Pb}^{2+}(1.33 \AA)$. Thus, changes in the parameters of the unit cells of the samples of the $\mathrm{Pb}_{(8-x)} \mathrm{Na}_{2} \mathrm{Sm}_{x}\left(\mathrm{PO}_{4}\right)_{6} \mathrm{O}_{x / 2}$ system indicate that the substitution limit is $x=1.13$.

Confirming the substitution limit by $\mathrm{Sm}$ for $\mathrm{Pb}$ in the apatite structure was carried out by the 'disappearing phase' method. In this method, the dependence of the absolute intensity of the peak of the (120) phase of samarium phosphate $\mathrm{SmPO}_{4}$ on the composition was plotted and is shown in Fig. 3. Extrapolation of the resulting straight line to the abscissa axis gives a value of substitution limit at $x=1.16$, in a good agreement with the value obtained by the unit-cell parameters' method, as shown above (Fig. 2).

The results of refinement of the crystal structure for some samples of this system by the Rietveld method are presented in Tables 2 and 3 and in Fig. 4.

A refinement of the crystal structure was carried out for a composi- 


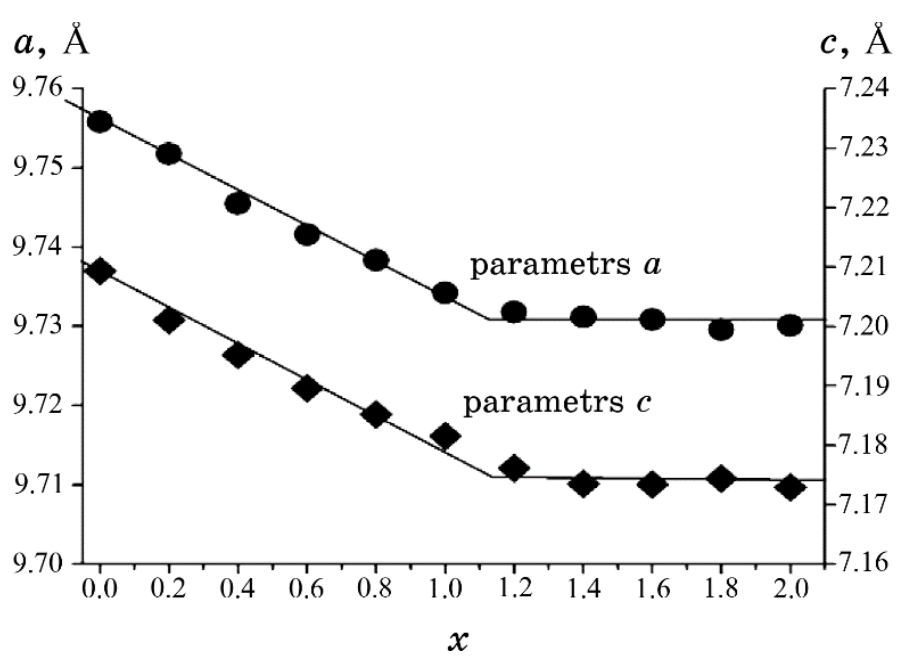

Fig. 2. Dependence of the lattice parameters $a$ and $c$ on the degree of substitution in $\mathrm{Pb}_{(8-x)} \mathrm{Sm}_{x} \mathrm{Na}_{2}\left(\mathrm{PO}_{4}\right)_{6} \mathrm{O}_{x / 2}$.

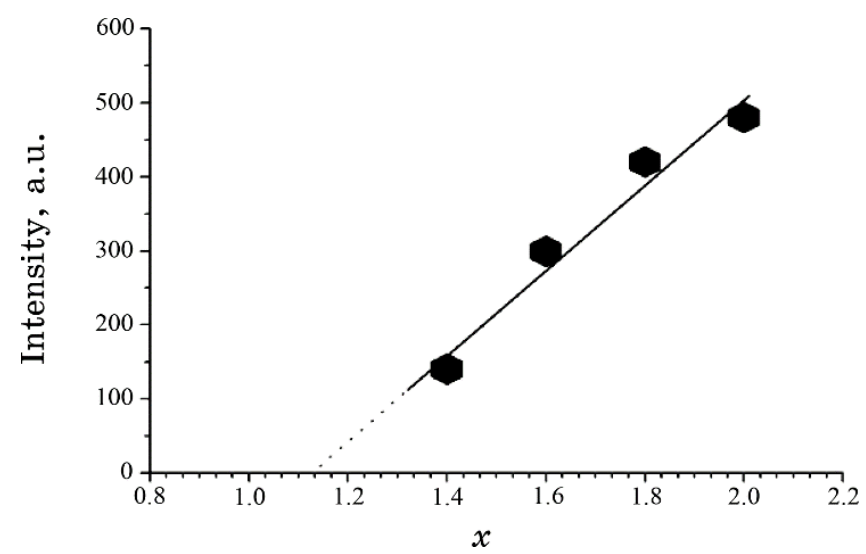

Fig. 3. Plot of the intensity of the phosphate samarium $\mathrm{SmPO}_{4}$ (120) reflection $v s$. degree of substitution, $x$.

tion $x=1.0$ with 863 reflections and 33 parameters. Factors of reliability were as follow: $5.55\left(R_{\mathrm{p}}\right) ; 8.03\left(R_{\mathrm{f}}\right) ; 8.17\left(R_{\mathrm{b}}\right) ; 1.69\left(\chi^{2}\right)$.

Since the effective charge of $\mathrm{Pb}^{2+}$ ions is smaller than the effective charge of $\mathrm{Sm}^{3+}$ ions, when substitution occurs in the apatite structure, $\mathrm{Pb}^{2+}$ ions are localized predominantly in the $\mathrm{Pb}(2)$ positions of the apatite structure, as shown in Table 2.

As a result of the refinement of the crystal structure, interatomic distances were calculated, some of which are given in Table 2. As can be seen from the Table, there is a decrease in the distances 
TABLE 2. Occupancy for the $\mathrm{Pb}(1)$ and $\mathrm{Pb}(2)$ positions in the system $\mathrm{Pb}_{(8-x)} \mathrm{Na}_{2} \mathrm{Sm}_{x}\left(\mathrm{PO}_{4}\right)_{6} \mathrm{O}_{x / 2}$.

\begin{tabular}{c|c|c}
\hline The positions of atoms & $x=0$ & $x=1.0$ \\
\hline $\mathrm{Pb}(1)$ (4f -position) & 2.059 & 1.651 \\
$\mathrm{Na}(1)$ (4f-position) & 1.979 & 1.998 \\
$\mathrm{Sm}(1)$ (4f-position) & - & 0.354 \\
$\mathrm{~Pb}(2)(6 h$-position) & 5.941 & 5.348 \\
$\mathrm{Sm}(2)(6 h$-position) & - & 0.647 \\
$\mathrm{Na}(2)(6 h$-position) & 0.021 & 0 \\
\hline
\end{tabular}

TABLE 3. Selected mean interatomic distances ( $(\AA)$ in the system $\mathrm{Pb}_{(8-x)} \mathrm{Na}_{2} \mathrm{Sm}_{x}\left(\mathrm{PO}_{4}\right)_{6} \mathrm{O}_{x / 2}$.

\begin{tabular}{c|c|c}
\hline Mean interatomic distances & $x=0$ & $x=1.0$ \\
\hline $\mathrm{Pb}(1)-\mathrm{O}(1,2,3)$ & $2.628(6)$ & $2.676(7)$ \\
$\mathrm{Pb}(2)-\mathrm{O}(1,2,3)$ & $2.509(9)$ & $2.435(8)$ \\
$\mathrm{Pb}(2)-(\mathrm{OH}), \mathrm{O}(4)$ & - & $2.497(7)$ \\
$\mathrm{Pb}(2)-\mathrm{Pb}(2)$ & $4.344(6)$ & $4.331(9)$ \\
$\mathrm{Pb}(2)-\mathrm{O}(2)$ & $2.25(3)$ & $1.955(8)$ \\
\hline
\end{tabular}

$\mathrm{Pb}(2)-\mathrm{O}(1,2,3)$ and an increase in $\mathrm{Pb}(1)-\mathrm{O}(1,2,3)$.

All bands are shown in the IR absorption spectra (Fig. 5). The IR spectra of studied samples $(x=0.0, x=0.2, x=0.4, x=0.6)$ were detected in the region of the internal vibrations of phosphate anions, which are assigned according to the data for $\mathrm{Pb}_{8} \mathrm{Na}_{2}\left(\mathrm{PO}_{4}\right)_{6}$ [18]. Thus, when $v_{2}\left(445 \mathrm{~cm}^{-1}\right), v_{3}(987,1051)$, and $v_{4}(539,580)$ enter into the vibrational structure of Sm atoms, the frequencies increase by $2-6 \mathrm{~cm}^{-1}$.

Vibrations in molecules of adsorbed water cause wide bands in the 1600 and $2500 \mathrm{~cm}^{-1}$ regions. In addition, there is a band at 631 $\mathrm{cm}^{-1}$, the intensity of which grows with increasing $x$. Perhaps, it refers to the vibrations caused by the bond of REE (rare earth elements)-oxygen or liberation vibrations to the $\mathrm{OH}^{-}$group, which are not part of the water.

The chemical compositions (wt. $\%)$ of samples $(x=0.0,0.4,0.6)$ for the $\mathrm{Pb}_{(8-x)} \mathrm{Na}_{2} \mathrm{Sm}_{x}\left(\mathrm{PO}_{4}\right)_{6} \mathrm{O}_{x / 2}$ system were determined by SEM (scanning electron microscopy) of $\mathrm{Pb}, \mathrm{P}, \mathrm{Sm}, \mathrm{Na}$ and $\mathrm{O}$, and the results are presented in the data below (Table 4 and Fig. 6). As seen from data, there is a good agreement between the founded and calculated contents of the elements.

Figure 6 shows the elements ( $\mathrm{Pb}, \mathrm{P}, \mathrm{Sm}, \mathrm{Na}$ and $\mathrm{O})$, which are virtually and uniformly distributed over the surface of the particle and manifest the homogeneity of the sample where the substitution 


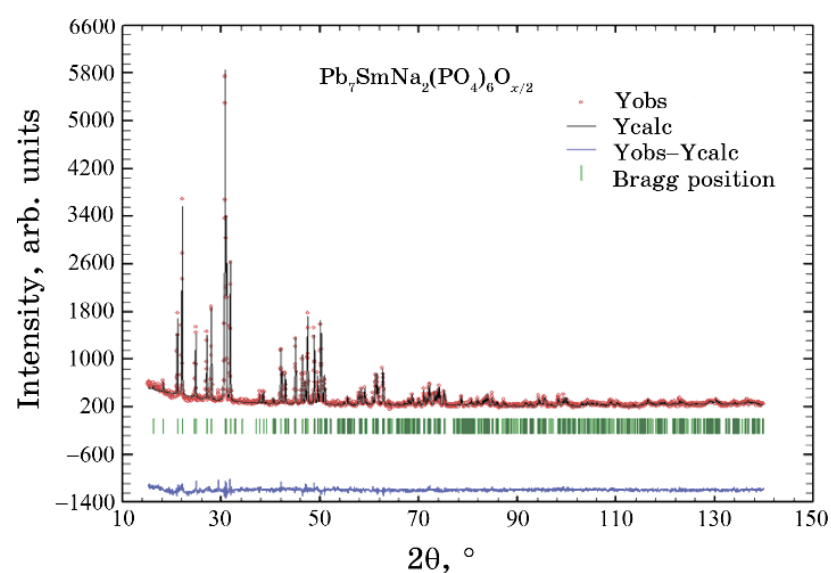

Fig. 4. The experimental and calculated $\mathrm{X}$-ray diffraction patterns and their difference for the sample composition $\mathrm{Pb}_{7} \mathrm{SmNa}_{2}\left(\mathrm{PO}_{4}\right)_{6} \mathrm{O}_{0.5}$.

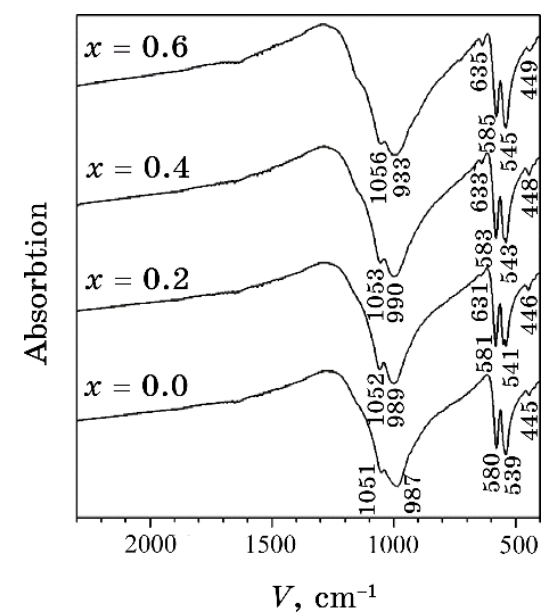

Fig. 5. IR absorption spectra of samples in the $\mathrm{Pb}_{(8-x)} \mathrm{Sm}_{x} \mathrm{Na}_{2}\left(\mathrm{PO}_{4}\right)_{6} \mathrm{O}_{x / 2}$ system.

processes occur. Some inhomogeneity can also be noticed on the surface and can be associated with the surface relief of particle [19].

\section{CONCLUSION}

Substitution by $\mathrm{Sm}$ for $\mathrm{Pb}$ in lead sodium apatite structure $\mathrm{Pb}_{\left(8^{-} x\right)} \mathrm{Sm}_{x} \mathrm{Na}_{2}\left(\mathrm{PO}_{4}\right)_{6} \mathrm{O}_{x / 2}$ was carried out at $850^{\circ} \mathrm{C}$. Annealing takes a long time (60 hours) in order to obtain an equilibrium and stable phase composition. Samarium ions substitute for $\mathrm{Pb}^{2+}$ ones mainly at $\mathrm{Pb}(2)$ loca- 
TABLE 4. Results of the SEM of $\mathrm{Pb}_{(8-x)} \mathrm{Na}_{2} \mathrm{Sm}_{x}\left(\mathrm{PO}_{4}\right)_{6} \mathrm{O}_{x / 2}$ for $x=0.0, x=0.4$ and $x=0.6$ (wt. $\%$ ), which were synthesized by solid-state reaction at $850^{\circ} \mathrm{C}$.

\begin{tabular}{|c|c|c|c|c|c|c|c|c|c|c|}
\hline \multirow{2}{*}{$x$} & \multicolumn{2}{|c|}{$\mathrm{P}$} & \multicolumn{2}{|c|}{$\mathrm{Pb}$} & \multicolumn{2}{|c|}{$\mathrm{Sm}$} & \multicolumn{2}{|c|}{$\mathrm{Na}$} & \multicolumn{2}{|c|}{$\mathrm{O}$} \\
\hline & Calcd & found & Calcd & found & Calcd & found & Calcd & found & Calcd & found \\
\hline 0.0 & 8.18 & 8.66 & 72.80 & 74.50 & - & - & 2.02 & 1.63 & 16.90 & 15.21 \\
\hline 0.4 & 8.25 & 8.50 & 69.87 & 69.30 & 2.66 & 2.58 & 2.04 & 1.43 & 17.18 & 18.19 \\
\hline 0.6 & 8.28 & 8.58 & 68.33 & 68.21 & 4.02 & 4.23 & 2.05 & 1.91 & 17.32 & 17.07 \\
\hline
\end{tabular}

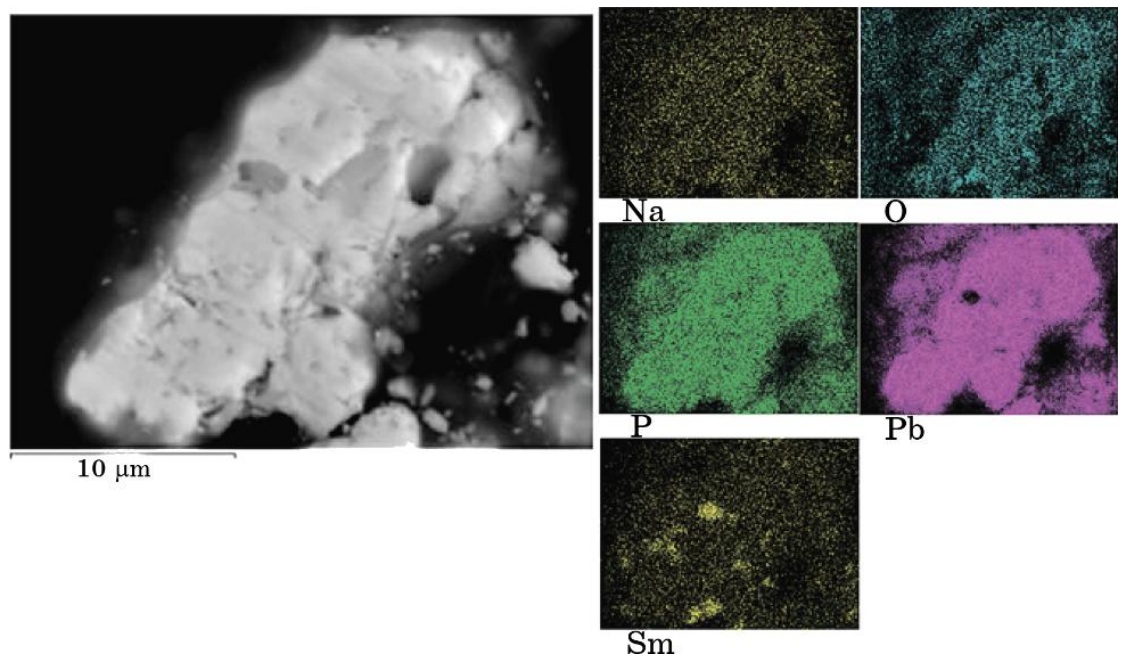

Fig. 6. Microphotography and distribution of elements over the surface for the sample composition $\mathrm{Pb}_{7.6} \mathrm{Sm}_{0.4} \mathrm{Na}_{2}\left(\mathrm{PO}_{4}\right)_{6} \mathrm{O}_{0.2}$.

tions with increasing of anions $\mathrm{O}^{2-}$ in imperfect hexagonal structural tunnels depending on the schema $2 \mathrm{~Pb}^{2+}+\square \rightarrow 2 \mathrm{Sm}^{3+}+\mathrm{O}^{2-}$. The substitution process gives two reverse effects (decrease and increase) on the unit cell parameters (parameters $a$ and $c$ ) and interatomic distances; a decrease is given because of the location-dependent accommodation of smaller samarium ion in $\mathrm{Pb}^{2+}$ locations, and an increase is given because of the filling of the empty channels with oxygen ions $\left(\mathrm{O}^{2-}\right)$. The interaction of these factors results in a much smaller change of parameters $a$ and $c$ as well as practical constancy of interatomic $\mathrm{Pb} 2-\mathrm{Pb} 2$ and $\mathrm{Pb} 2-\mathrm{O} 4$ distances with increasing limit of substitution. In this subject, samarium ion substitution in the apatite acts quite differently from what has been observed in largely studied alkaline-earth hydroxyapatites and fluorapatites with filled hexagonal channels.

Hence, substitution by samarium ion $\mathrm{Sm}^{3+}$ for lead ion $\mathrm{Pb}^{2+}$ in the apatite system $\mathrm{Pb}_{8} \mathrm{Na}_{2}\left(\mathrm{PO}_{4}\right)_{6}$ is controlled not only by the location-dependent and charge accommodation of Sm ion but also by the attainability of the 
stereochemically active electron pair $6 s^{2}$ on $\mathrm{Pb}^{2+}$. Depending on the results attained above, it is necessary to enlarge further studies for new functional materials with apatite structure.

\section{ACKNOWLEDGMENTS}

I appreciated all the support, which were presented by Department of Inorganic Chemistry, Donetsk National University, Donetsk, Ukraine, during preparing, measuring and analyzing the samples in this work.

\section{REFERENCES}

1. L. Bragg and G. Claringbull, Crystalline Structure of Minerals (Moscow: Mir: 1967) (Russian translation).

2. J. Rakovan, R. J. Reeder, E. J. Elzinga, D. J. Cherniak, C. D. Tait, D. E. Morriss, Environmental Science \& Technology, 36, No. 14: 3114 (2002);

DOI: $10.1021 /$ es015874f.

3. M. Manecki, P. A. Maurice, S. J. Traina, Am. Miner., 85, Nos. 7-8: 932 (2000).

4. V. Laperche, T. J. Logan, P. Gaddam, and S. J. Traina, Environmental Science \& Technology, 31, No. 10: 2745 (1997).

5. H. Owada, K. Yamashita, T. Umegaki, T. Kanazawa, and M. Nagai, Solid State Ionics, 35, Nos. 3-4: 401 (1989).

6. G. Blasse, Journal of Solid State Chemistry, 14, No. 2: 181 (1975).

7. M. Gaft, R. Reisfeld, G. Panczer, E. Uspensky, B. Varrel, and G. Boulon, Optic. Mater., 13, No. 1: 71 (1999).

8. E. Cantelar, G. Lifante, T. Calderón, R. Meleóndrez, A. Millaón, M. A. Alvarez, M. Barboza-Flores, Journal of Alloys and Compounds, 323-324: 851 (2001).

9. A. Serret, M. V. Cabanas, and M. Vallet-Regi, Chemistry of Materials, 12, No. 12: 3836 (2000); doi: $10.1021 / \mathrm{cm} 001117 \mathrm{p}$.

10. E. I. Get'man, N. V. Yablochkova, S. N. Loboda, V. V. Prisedsky, V. P. Antonovich, and N. A. Chivireva, Journal of Solid State Chemistry, 181, No. 9: 2386 (2008).

11. L. Ardanova, E. Get'man, S. Loboda, V. Prisedsky, T. Tkachenko, V. Marchenko, V. Antonovich, N. Chivireva, K. Chebishev, and A. Lyashenko, Inorg. Chem., 49, No. 22: 10687 (2010).

12. R. Verbeeck, C. Lassuyt, H. Heijligers, F. Driessens, and J. Vrolijk, Calcified Tissue International, 33, No. 1: 243 (1981).

13. L. Brixner and P. Bierstedt, Journal of Solid State Chemistry, 13, Nos. 1-2: 24 (1975).

14. J. Rodriguez-Carvajal, Fullprof. 2k: Computer Program (2011).

15. J. Rodriguez-Carvajal, Newsletter, 26: No. 12 (2001).

16. D. Arcos, J. Rodriguez-Carvajal, and M. Vallet-Regi, Chemical Materials, 17, No. 1: 57 (2005).

17. K. Brandenburg and H. Putz, Match Software for Phase Identification from Powder Diffraction Data, Computer Program (2014); http://www.crystalimpact.com.

18. N. A. Zakharov, Technical Physics Letters, 27, No. 12: 1035 (2001).

19. E. I. Get'man, S. N. Loboda, A. V. Ignatov, V. V. Prisedsky, M. A. B. Abdul Jabar, and L. I. Ardanova, American Chemical Society, 55, No. 5: 2165 (2016). 